\title{
Patterns for Resilient Value Creation: Perspective of the German Electrical Industry during the COVID-19 Pandemic
}

\author{
Konstantin Neumann $^{1, *(\mathbb{D}}$, Tim van Erp ${ }^{2,3}{ }^{\mathbb{C}}$, Erik Steinhöfel ${ }^{1}{ }^{(\mathbb{D}}$, Felix Sieckmann ${ }^{1}$ and Holger Kohl ${ }^{1,4}{ }^{(\mathbb{D}}$ \\ 1 Fraunhofer Institute for Production Systems and Design Technology, 10587 Berlin, Germany; \\ mail@eriksteinhoefel.de (E.S.); felix.sieckmann@ipk.fraunhofer.de (F.S.); holger.kohl@ipk.fraunhofer.de (H.K.) \\ 2 German Electrical and Electronic Manufacturers' Association (ZVEI), 60528 Frankfurt am Main, Germany; \\ Tim.vanErp@zvei.org \\ 3 Department of Technology and Innovation, University of Southern Denmark, 5230 Odense, Denmark; \\ tve@iti.sdu.dk \\ 4 Chair for Sustainable Corporate Development, Technische Universität Berlin, 10587 Berlin, Germany \\ * Correspondence: konstantin.neumann@ipk.fraunhofer.de; Tel.: +49-30-39006-139
}

check for

updates

Citation: Neumann, K.; van Erp, T.; Steinhöfel, E.; Sieckmann, F.; Kohl, H. Patterns for Resilient Value Creation: Perspective of the German Electrical Industry during the COVID-19 Pandemic. Sustainability 2021, 13, 6090. https://doi.org/10.3390/ su13116090

Academic Editor:

Ali Bahadori-Jahromi

Received: 31 March 2021

Accepted: 24 May 2021

Published: 28 May 2021

Publisher's Note: MDPI stays neutral with regard to jurisdictional claims in published maps and institutional affiliations.

Copyright: (c) 2021 by the authors. Licensee MDPI, Basel, Switzerland. This article is an open access article distributed under the terms and conditions of the Creative Commons Attribution (CC BY) license (https:/ / creativecommons.org/licenses/by/ $4.0 /)$.

\begin{abstract}
The COVID-19 pandemic represents a massive, often unanticipated, external disruption for many companies. As a concept for responding to such disruption, organizational resilience has recently received great attention. In the organizational context, the overriding question is how companies can become more resilient. This study aims to contribute to answering this question by identifying, categorizing, and providing specific business model patterns for achieving resilience on the corporate level. For this purpose, a review of publications by major consulting firms was conducted. Patterns were extracted from publications until a convergence criterion indicated that no new pattern could be identified considering further publications. The 110 extracted unique patterns were clustered into 13 objectives, and additionally categorized according to resilience phases, as well as business model elements, to support the application in practice. The final catalog of patterns was validated through expert interviews and thus provides organizations, such as those in the electrical industry, with an overview and specific approaches on how to tackle industrial resilience through the adaption of their business model.
\end{abstract}

Keywords: organizational resilience; business model; resilience measure; business model pattern; COVID-19; pandemic; crisis; risk management; business continuity; electrical industry

\section{Introduction \\ 1.1. Motivation}

Against the backdrop of increasing volatility in business environments, organizational resilience is receiving significant attention from research and practice. The current pandemic is accompanied by changing consumer patterns and behavior, disrupted supply chains and the need for effective health measures, among other factors. This underscores the importance of being able to anticipate potential threats, cope effectively with adverse events and adapt to changing conditions.

The concept addressing this ability is resilience. Existing literature covers the concept [1-3] of resilience and, based on literature reviews [1,3-7] or case studies [2,8,9], general principles and attributes of resilient organizations, or parts of organizations like supply chains [10], are discussed. To help companies cope with volatility in the short term and achieve resilience in the long run, it is essential to provide them with practical and effective tools [9]. For example, Mallak [11] provides principles and suggests how to apply them. Fiksel et al. [12] also provide a practitioner-focused description; however, their analysis is on supply chains. Although a variety of general and sustainability-oriented business model pattern collections exist (e.g., [13]), as well as approaches for developing resilient business models (e.g., [14]), no pattern collection focusing on resilience is yet available. Therefore, 
this study aims at closing this research gap by developing such a pattern collection against the background of the COVID-19 pandemic. The German electrical industry was chosen for validation as they faced several impacts of the pandemic situation.

For this purpose, it is first pointed out how resilience fits into the concept of systems engineering and sustainability. Afterward, using the example of the German electrical industry, the results of a current survey illustrate the impact of the pandemic at various levels. Subsequently, the concept of resilience and the concept of the business model are outlined and brought together to guide the following developments. Based on a review of contributions on resilience by the main players in the consulting industry, measures or so-called business model patterns are identified, classified, and validated through expert interviews. The insights gained are used to provide recommendations for practice and research. In conclusion, the results of the paper are summarized and an outlook for further research and development is given.

\subsection{Academic Relevance: Contributions to Systems Engineering and Sustainable Development}

The logic of how companies create value is a key element of value creation systems. Understanding value and considering customers, users, other beneficiaries, and suppliers is an essential activity of model-based systems engineering [15]. Business models provide a common, conceptual modeling framework for describing this logic, by defining key elements and their relationships. Developing or innovating business models is thus an important aspect supporting the engineering of complex industrial systems. For example, it supplements the hardware and software of technical innovations [16]. Resilient business model patterns can serve as principles and recommendations as well as best-practice examples for designing complex value creation systems, and thus contribute to research in systems engineering, specifically with relevance to business engineering and to designing innovation systems.

The Sustainable Development Goals (SDGs) of the United Nation aim to enable transformation to move toward a global state of sustainability. This state can change dynamically over time, and is described by a current global consensus, i.e., the SDGs [17]. Sustainable transformation can be divided into two main components: mitigation and adaptation [18]. Mitigation aims at eliminating the underlying negative causes for global trends and their connected risks, whereas adapting aims at building up resilience against global risks by increasing the capability to appropriately react to shocks. Thus, resilience is a possible answer for organizations to adjust to climate change, for instance, with its uncertain consequences or other unknown disturbances. This directly contributes to SDG targets 13.1 and 13.3 [19]. In the literature, it is argued that there is a relationship between the different areas of resilience, e.g., that resilient organizations can lead to resilient communities [9]. Therefore, resilience also facilitates SDG targets 9.1 and 11.b [20,21]. Furthermore, it is shown that social and environmental practices have a positive effect on long-term metrics, and researchers have argued that they therefore support resilience [22]. Hence, this paper intends to contribute directly to research approaches supporting sustainability and the SDGs. It provides a holistic view on how to achieve a higher state of resilience in value creation systems, helping industrial stakeholders to adapt to global sustainability risks.

\subsection{Industrial Relevance: Impacts of the COVID-19 Crisis on the Electrical Industry}

The electrical industry in Germany is represented by ZVEI, the German Electrical and Electronic Manufacturers' Association. ZVEI has more than 1600 member companies, which account for approximately $90 \%$ of the employees of the electrical industry in Germany. Its member structure comprises global players as well as medium-sized and family-owned companies. ZVEI's members employ 867,500 people in Germany, and an additional 790,000 people globally. The sector generated a turnover of approximately 181.9 billion Euros in 2020. The electrical industry accounts for $10 \%$ of industrial turnover, $14 \%$ of total employees, as well as 3\% of the gross domestic product of Germany in 2020 [23]. Its companies employ $26 \%$ of all employees in the area of research and development, are 
responsible for $23 \%$ of innovation expenditures of the manufacturing industry, and realize one-third of their turnover with product innovations.

The electrical industry is an essential supplier for the health, building and mobility industry as well as for the energy sector. Typical products are automation components and systems, batteries, consumer electronics, home appliances, microelectronic components and systems, electric power tools, medical systems, and electrical installation systems, as well as electric traction systems and vehicles, among others [24]. Consequently, most of the business models of the electrical industry are B2B-oriented, with comparatively little B2C orientation addressing electrical consumer products such as home appliances. Value creation of the electrical industry is characterized by highly interconnected global networks [25].

In April, during the first wave of the COVID-19 pandemic, ZVEI conducted two surveys on the impact of the crisis on the electrical industry in Germany. 128 member companies participated in the survey at the beginning of April (4-7 April 2020). The participants comprised $24 \%$ ( 45 billion Euros) of the sector's turnover. 114 member companies participated in the second survey at the end of April (23-27 April 2020). The participants of this second survey comprised $41 \%$ (78 billion Euros) of the sector's turnover. Comparisons of selected results from both surveys are presented in Figures 1 and 2.

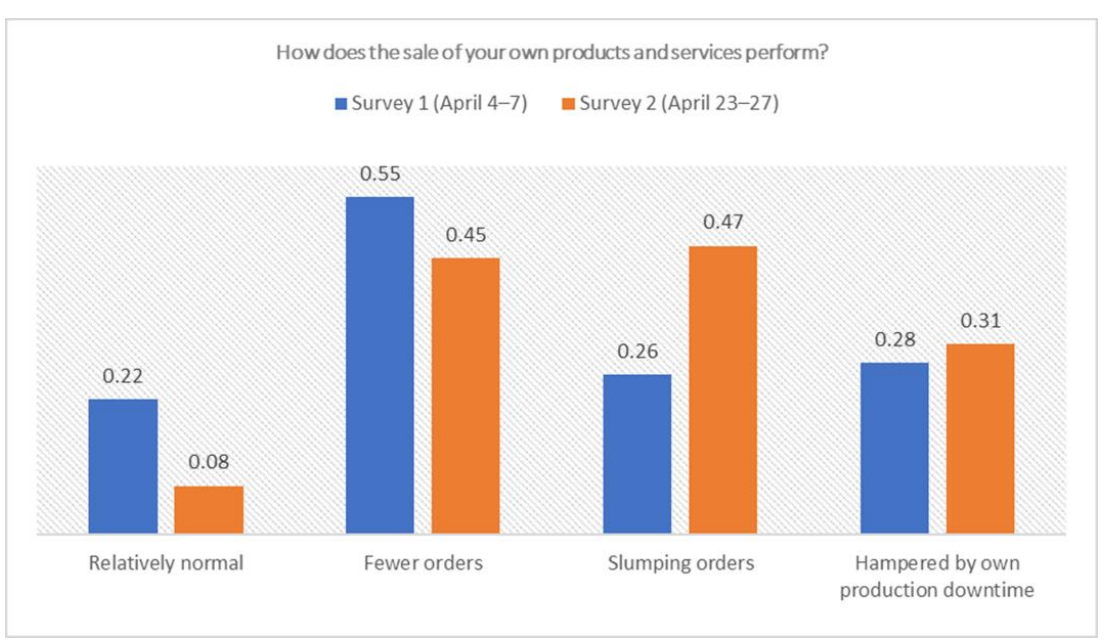

Figure 1. Impact of the COVID-19 crisis on orders in April. (Multiple answers possible, answers weighted by turnover, own illustration data from [26,27]).

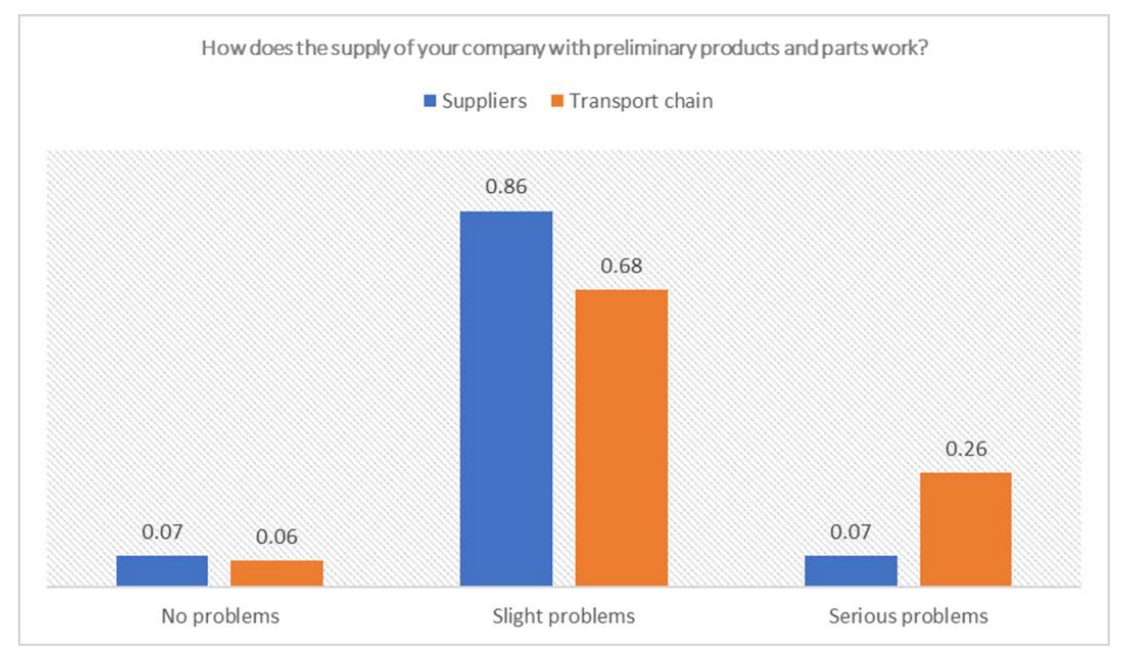

Figure 2. Impact of the COVID-19 crisis on the supply chain at the end of April 2020. (Multiple answers possible, answers weighted by turnover, own illustration data from [27].) 
In the first ZVEI survey, more than half of the participating companies (55\%) had already received fewer orders than before the crisis. $26 \%$ reported a slump in orders (see Figure 1). In the same survey, the companies expected sales to fall by an average of $14 \%$. Only $3 \%$ considered it realistic to completely make up for these losses within the near future. The rest expected to recover only half of them or even less in the foreseeable future [26]. In the second survey, $12 \%$ expected to make up for the loss [27].

In the second survey, $86 \%$ of the companies continued to report slight problems with their suppliers. For 7\%, the problems had taken on a serious level (see Figure 2). As far as the supply chain was concerned, $68 \%$ of companies were experiencing slight difficulties, and $26 \%$, serious difficulties. For around $90 \%$ of companies, sales of their own products and services had been impaired. In half of the cases, orders had collapsed. In just under a third of the companies, sales had also been disrupted due to their own production stoppages (see Figure 1) [27].

At the beginning of April 2020, the COVID-19 crisis had already hit the companies of Germany's electrical industry quite hard. In particular, a decrease in orders, as well as production downtime and limited supply chain functionality, hindered the production systems of the electrical industry. The impact of the crisis further increased over April, and the production conditions for the companies continued to deteriorate.

This snapshot of the situation in April is also evident when looking into the economic development of the electrical industry from January to October 2020. According to the ZVEI economic barometer in January 2021, orders were down 6.9\% compared to the same period in the previous year. In the first ten months of 2020, production was $8.1 \%$ lower than in the first ten months of 2019. In those ten months, the aggregate sector turnover amounted to 146.8 billion Euros, $7.2 \%$ short of the previous year's figure. In November $2020,26 \%$ of the sector's companies rated their current economic situation as good, $49 \%$ as stable, and $25 \%$ as poor. As far as expectations for the coming six months were concerned, $24 \%$ of the companies expected business to pick up, $61 \%$ expected it to remain stable, and $15 \%$ to slow down [28].

The COVID-19 crisis showed the vulnerability of global value creation networks, and led to negative impacts for the electrical industry in Germany with its complex, globally connected manufacturing systems. Resilient value creation approaches can enable industrial stakeholders to cope with future crises in a more efficient and effective manner. Resilient value creation is expected to reduce the negative impacts of internal and external shocks and contribute to the competitiveness of companies in a future that is increasingly shaped by the direct effect of climate change. In conclusion, the identification of specific patterns for resilient value creation, as intended by this paper, can be of substantial industrial relevance.

\section{Literature Review}

The aforementioned results exemplify the effect of an unexpected crisis on companies. This is where resilient value creation comes into play as an answer to the posed challenges. The concept of value creation, laid out in the following text, is based on a manufacturingoriented perspective as described by Stock et al. [29], and Stock and Seliger [30]. Companies create value by linking value creation modules of different aggregation levels, e.g., factories, production lines or assembly workspaces, in horizontally and vertically integrated global networks. Individual business models define and frame the activities of stakeholders involved throughout the value creation network, and lead to cooperation and competition among them.

\subsection{Resilient Value Creation}

Organizations must continuously prove themselves against adverse events that can have a negative impact on them. Enterprise risk management and business continuity management are established approaches that support businesses in acting proactively and reactively. These approaches are based on risk identification, which is difficult because they 
depend on knowledge about the nature of the adverse events, as well as their occurrence probability and impact [12]. Additionally, these methods usually assume the independence of risks, which in today's complex systems and networks is questionable [31]. Furthermore, Fiksel et al. [12] argue that the process of risk management is too simplified, and learning opportunities are not considered, as risk management always assumes a return to its initial state. They conclude that, while building resilience might not be a substitute for other risk management approaches, it is an approach that continuously adapts to changing circumstances and can give a competitive advantage by building capabilities [12].

The term "technological sovereignty" is strongly related to the topic of resilience. It is defined as "the ability of governing bodies to choose and take political, economic, and scientific measures of their own within the operational framework of their international commitments. The aim is to protect well-defined system-critical infrastructures, including the competence to control risks associated with the use of certain technologies" [32] (p. 3). The COVID-19 crisis, especially at the beginning of the pandemic when global supply chains were massively disrupted, demonstrated the dependency of European society on products imported from non-European countries, leading to increasing global competition and tensions in international trade [32]. The capability to provide key technologies without relying on third countries is now an ongoing political discussion. Technological sovereignty thus describes the actions of a government on a macroeconomic level to ensure independence in clearly defined core areas of great social-economic relevance, whereas resilience covers the actions of individual companies on a microeconomic level for increasing the ability to cope with shocks of different sorts.

The overview of the development of the term, "resilience", by Linnenluecke [33] identifies the origins of the concept in publications as early as 1981 . The term is used in several contexts such as psychology, ecosystems, infrastructure, etc. Bhamra et al. [1] see the common definition across all fields of resilience as the "capability and ability of an element to return to a stable state after disruption" [1] (p. 5376), although the context might change from an ecological, individual or organizational perspective. McManus et al. [9] point out that there is a connection between the different fields and perspectives of resilience, as resilient organizations can lead to resilient communities.

Previous research on the topic of resilience has shown that there are different definitions of the term [3], and the research itself is divided into several research streams, one of them being the "adaptability of business models" [33]. Duchek [3] identifies three scholarly groups. The first one views resilience as the ability to resist and recover, and the second one focuses on the development "of organizational processes and capabilities", while the last group also brings anticipation into its scope.

Collections of definitions of resilience in the organizational context (and others) can be found, for instance, in Bhamra et al. [1], Kamalahmadi and Parast [5], Linnenluecke [33] and Duchek [3]. So far, there is a lack of consistent conceptualization [3,33].

The measurement of resilience is an ongoing research topic; however most studies measure resilience after specific events, predictive factors are missing [33]. Ruiz-Martin et al. [6] suggest the four levels of fragile, robust, resilient, and antifragile to classify the resilience level, and note that these can change over time. The measurement itself is not the topic of this article. However, it is assumed that achieving higher states of resilience is possible.

To conceptualize resilience, and for ease of understanding the concept, Thoma [34] suggests a resilience cycle consisting of five phases-prepare, prevent, protect, respond and recover-based on approaches from classical disaster management. Duchek [3] uses a three-phase approach that includes anticipation, coping and adaptation. During the first phase, which Duchek [3] defines as an offensive one, the organization should observe its environment and prepare for unexpected events. This is followed by the coping phase, where actions are conducted as a response to the event and adaptation after the event, where the organization should transform and adapt based on learning from the crisis it has undergone [3]. Following this approach, in this study, three phases are applied for ease 
of usage and increased practical applicability. However, within the first phase, we also include resistance to an unexpected event as a possible reaction and not only adaptation.

Based on the existing definitions from Ruiz-Martin et al. [6], and Vogus and Sutcliffe [7], for the purpose of the paper we define resilient value creation as follows: the ability, capacity or capability of value creation systems, including its stakeholders, to return to a competitive state (which can be based on a different business model than before) by preparing for, responding to, and recovering from internal or external and known or unknown disturbances.

Thus, measures of resilient value creation can be characterized by combining different business model activities throughout the phases of anticipation, coping and adaptation of the resilience cycle.

\subsection{Business Models and Business Model Patterns}

As mentioned before, "working constructs that are practical and effective in the short and long term" [9] are essential for achieving corporate resilience. Business models can be understood as such constructs as they allow, depicting and thereby capturing organizations with all their elements and respective characteristics in their entirety [35-37]. Furthermore, they allow the adequate analysis and design of organizations [38,39]. In this context, generating value for the organization and its stakeholders represents the overall goal [35-37,40], through which competitive advantage can be realized and organizations' survival can be secured $[35,37,41]$.

In the context of this paper, resilience can thus also be understood as an organization's capability to always have an adequate business model at hand for both short-term and long-term competitiveness, and thereby, survive. For the generation of business models, a variety of approaches exist [36,42].

A particularly promising, efficient and effective approach is the application of so-called business model patterns $[13,43,44]$. In the relevant literature, business model patterns are generally understood as design options for the configurations of a business model which has proven successful in practice, and represents solutions for recurring problems [44-46]. In addition to the term "business model pattern", different terminologies are used: business model analogies [47]; atomic business models [48]; operating business models [49]; profit models [50]; business models [51]; business model configurations [52]; and business model archetypes [53].

Business model patterns can refer to both a business model as a whole and to individual elements of a business model $[47,54]$. A business model can thus represent a combination of different patterns. According to Gassmann et al. [46], business model patterns are of particular importance, because their analysis of disruptive business models over the last 50 years shows that more than $90 \%$ of all business model innovations are merely recombinations of known ideas, concepts, and elements of business models from other industries. Against this backdrop, leveraging business model patterns that have proven successful in other industries and companies offer an efficient approach for generating business models and for decision support $[13,44,55]$. To date, a variety of business model pattern collections with different focuses have been created [13,42,43,56,57]. In this context, the focus has been put on different industries and businesses such as banking [58], car-sharing [56], destination management [59], e-business [38,60-62], e-mobility [63], open data [64], the internet of things [65], insurance [66], social business [67,68] and utility computing [69], as well as industry-independent generic patterns [43,52,57,70]. In addition, a variety of pattern collections have been dedicated to the field of sustainability [13,71-75], focusing on the areas of economic, environmental and social dimensions in the frame of business models and their development. Regardless of the respective focus, the development of pattern collections is carried out both by means of literature analyses, taking into account scientific and non-scientific articles (e.g., [43]), and based on empirical research (e.g., [46]), as well as by means of conceptual work (e.g., [62]), and combinations of the different approaches (e.g., [58]). 
To the best of the authors' knowledge, so far, no specific collection that focuses on business model patterns with regard to resilience is yet available. Complementary to existing general and sustainability-focused pattern collections, as well as further approaches for designing resilient and sustainable business models (e.g., [14,76]), a generic pattern collection dedicated to resilience seems promising, and thus illustrates a promising approach for supporting organizations in becoming and remaining resilient.

\section{Methodology}

To investigate which business model patterns are relevant for resilient value creation during COVID-19, and what can be learned for future crises, this research focused on the recommendations and findings of globally operating business consultancies. At the beginning of the pandemic, only a few academic publications on resilience during the COVID-19 crisis were available. In contrast, consultancies were able to publish their experiences ad hoc without the need of going through academic review procedures. Therefore, this study's methodology focuses on the consultancies' insights in order to gain practical-oriented knowledge with high relevance for the industry. Thus, the research results provide an overview of the resilience experiences from global consultancies during the beginning of the COVID-19 crisis.

The research methodology followed the algorithm shown in Figure 3. To support the procedure, Microsoft Excel was used. First, relevant sources were identified by analyzing resilience-related open-access publications of established business consultancies, sourced from their websites. For starting the algorithm, a consultancy was randomly selected from a list of the top 10 consultants by revenue [77], and searched for resilience-related content on their websites. For the respective consultancy under consideration, the relevant content, i.e., individual sources, was then extracted. Subsequently, in each of these publications, relevant statements were identified. A statement represents a self-contained approach for resilient value creation. From each single statement, specific objectives and patterns were condensed and transferred into one list. In the next step, the novelty of the identified patterns was checked by comparing them all before capturing anonymized patterns. After processing each publication, it was evaluated regarding a pre-defined convergence criterion. The convergence criterion was defined as the number of new patterns of a publication divided by all patterns of that publication. For the threshold, $10 \%$ was determined. This allowed monitoring of the knowledge gain during the research process. In the case that newly sourced statements repeatedly did not contribute new knowledge in terms of unique patterns, and convergence was reached, the review was stopped. Eventually, four different consultancies (BCG, McKinsey, Deloitte, EY; $\mathrm{k}=4$ ) and 10 related publications $(\mathrm{p}=10)$ were analyzed, leading to 171 statements $(\mathrm{m}=171)$. From these statements, 226 objectives $(n=226)$ and 245 patterns $(z=245)$ were derived. The convergence criterion for the final source equaled 0.077 , meaning that only $8 \%$ (or 1 out of 13 ) of the patterns derived from this source could be classified as novel. The two previous iterations reached 15\% (8 out of 54 ) and $25 \%$ ( 4 out of 16) regarding the convergence criterion. By reaching a value below 0.1 in the final iteration, the algorithm was exited.

Subsequently, the list of objectives and patterns, i.e., the "Bucket of Patterns", was processed. This step included a further clustering of the objectives and patterns in terms of similarity. This resulted in 13 objectives. Under each objective, similar patterns were then grouped together and reformulated as an actionable measure. At the same time, patterns that were too broad or general, or articulate an objective itself, were omitted. In total, this resulted in 110 unique patterns. In the next step, each of the remaining patterns was assigned to one or more resilience phases according to Duchek [3], based on its content. Furthermore, each pattern was assigned to one or more elements of the business model according to Osterwalder and Pigneur [36]. In the case where patterns affected the business model as a whole, they were assigned to an overarching business model level. 


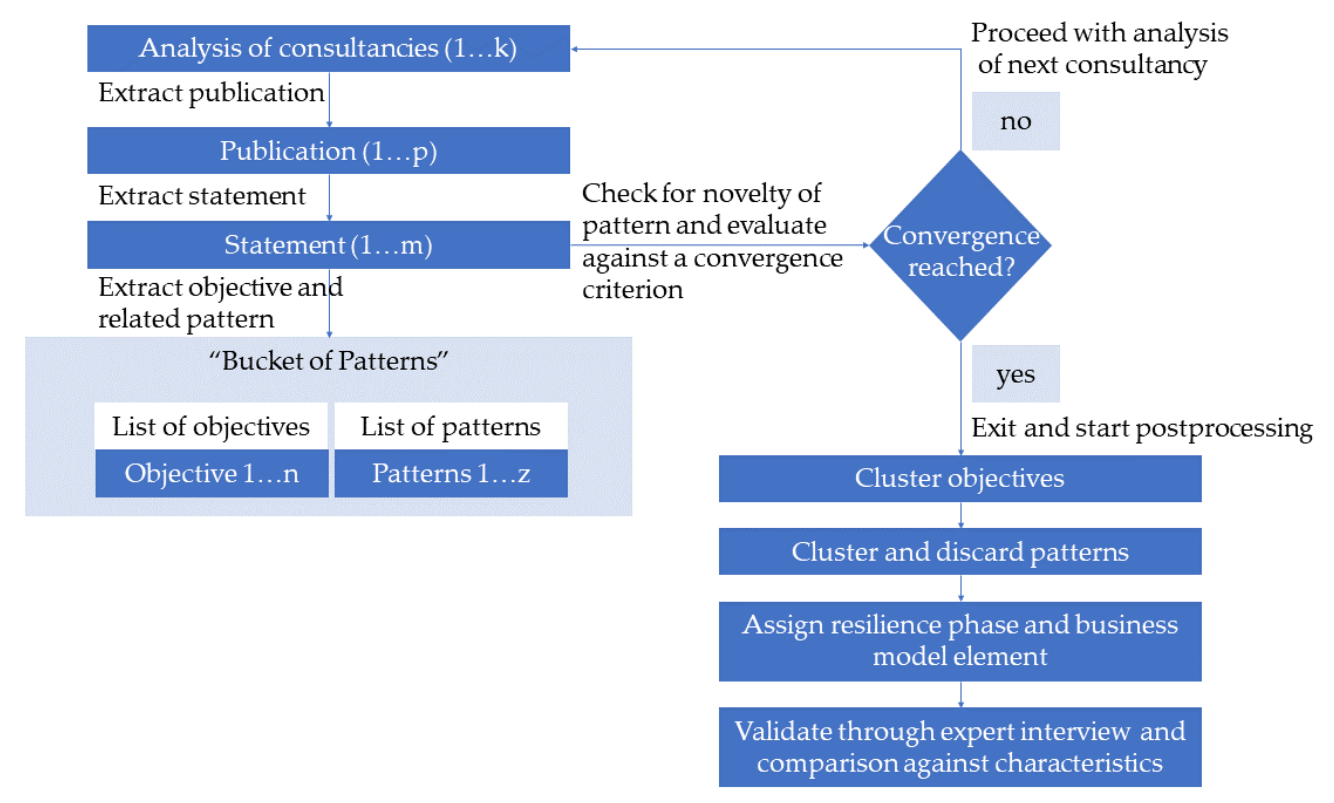

Figure 3. Research methodology.

As a result of this procedure, the pattern catalog comprised 13 objectives and 110 patterns, and was subsequently validated through semi-structured interviews with 3 experts from the electrical industry. The identified patterns were also compared with the aforementioned characteristics of the German electrical industry. In conclusion, the main result of this research is a qualitative meta-study of validated patterns for industrial resilience, based on the practical experiences of well-established business consultancies. The results of this approach are presented in the following section.

\section{Results and Validation}

This section takes a closer look at the objectives, the patterns and their assignment to resilience phases and business model elements, before describing how the patterns were validated.

\subsection{Results}

The provided structure aimed at enabling practitioners to choose suitable patterns from the catalog according to their individual needs. All patterns are listed in Supplementary Table S1, which shows the 13 objectives, a short explanation and the number of patterns within each objective. As shown in Table 1, most patterns were assigned to the objective "ensure liquidity" while a few are assigned to "empower people and create culture" and "increase transparency of the value creation system". However, the number of patterns per objective does not allow any conclusions about importance. For a discussion of the objectives against the literature and their relevance, see Section 5.

Table 1. Identified objectives of resilient value creation and number of patterns per objective.

\begin{tabular}{|c|l|c|}
\hline Objective & \multicolumn{1}{|c|}{ Brief Explanation } & Number of Patterns \\
\hline Adapt and align leadership & $\begin{array}{l}\text { All changes which are necessary in the leadership style of the } \\
\text { organization and the strategic orientation. }\end{array}$ & 10 \\
\hline Anticipate change in customer demand & $\begin{array}{l}\text { Identify at an early stage how customer needs and } \\
\text { distribution channels are changing, e.g., towards digital sales. }\end{array}$ & 10 \\
\hline Anticipate moment of rebound & $\begin{array}{l}\text { Identify early on when the disturbance is over, and then } \\
\text { prepare accordingly to ensure a smooth and fast ramping-up } \\
\text { of operations. }\end{array}$ & 6 \\
\hline $\begin{array}{c}\text { Create awareness on different scenarios } \\
\text { and risks }\end{array}$ & $\begin{array}{l}\text { Facilitate better understanding about the occurrence and } \\
\text { effects of possible adverse events, as well as } \\
\text { feasible countermeasures. }\end{array}$ \\
\hline
\end{tabular}


Table 1. Cont.

\begin{tabular}{|c|c|c|}
\hline Objective & $\begin{array}{l}\text { Brief Explanation } \\
\end{array}$ & Number of Patterns \\
\hline Design a flexible system & $\begin{array}{l}\text { Create a system and its components, be it individual } \\
\text { organizations, supply chain or technical systems, to be } \\
\text { easily modified. }\end{array}$ & 10 \\
\hline $\begin{array}{l}\text { Empower people and create } \\
\text { culture }\end{array}$ & $\begin{array}{l}\text { Build competencies and motivation to create a higher } \\
\text { individual resilience, as well as facilitate a cultural framework } \\
\text { in which people can act resiliently. }\end{array}$ & 5 \\
\hline Enable agile actions & $\begin{array}{l}\text { Facilitate quick and easy response to any changes } \\
\text { when necessary. }\end{array}$ & 8 \\
\hline $\begin{array}{c}\text { Ensure employees' safety (in a health } \\
\text { crisis) }\end{array}$ & $\begin{array}{l}\text { Guarantee the physical and emotional wellbeing of the } \\
\text { employees, especially in a health crisis. }\end{array}$ & 8 \\
\hline Ensure liquidity & $\begin{array}{l}\text { Stay on top of finances to have sufficient cash available or be } \\
\text { able to convert assets quickly into cash. }\end{array}$ & 15 \\
\hline Identify revenue opportunities & $\begin{array}{l}\text { Question product and service listing and reorganize } \\
\text { if necessary. }\end{array}$ & 6 \\
\hline Increase robustness & $\begin{array}{l}\text { Create stability and reduce vulnerability to severe impacts by } \\
\text { increasing redundancy and diversity. }\end{array}$ & 6 \\
\hline $\begin{array}{l}\text { Increase transparency of the value } \\
\text { creation system }\end{array}$ & $\begin{array}{l}\text { Share information with suppliers and collect information, e.g., } \\
\text { by "control towers", and create visibility of material stocks. }\end{array}$ & 5 \\
\hline Use digital processes and work tools & $\begin{array}{l}\text { Digitalize the complete system from E2E, and use digital tools } \\
\text { to support employees. The basis is IT security, which is a } \\
\text { top priority. }\end{array}$ & 9 \\
\hline Total & & 110 \\
\hline
\end{tabular}

With regard to the distribution of patterns in relation to phases and objectives, different insights can be gained. As shown in Table 2, most patterns are assigned to the coping phase (65). This is followed by 48 patterns assigned to the adaptation phase, and 47 to the anticipation phase, as shown in Table 2. A possible explanation for this distribution among the phases might be the time frame of the study. It was conducted when most companies had to deal with the consequences of COVID-19, and consultancies tried to offer related solutions. Regarding the relationship between objectives and resilience phases, the data show that nearly all objectives are represented in more than one phase, except "anticipate moment of rebound". This objective is only present during adaptation. Contrary to the general focus on coping and adaptation, there is a clear relationship between the "creation of awareness" and the anticipation phase, which seems logical as it is most important before the disturbance affects organizations. In this way, organizations can react early and quickly. The objective "ensure liquidity" has a high relevance during the coping phase, as it is most crucial for organizations to stay on top of their finances during this phase. The objective "ensure employees' safety" was not represented during the anticipation phase, but it shows high representation during the coping phase. Building a robust operation needs a clear focus on anticipation, with no patterns assigned to adaptation. The advancement in digital processes shows little relevance during the adaptation phase. When discussing this topic, it is important to consider that the process of becoming resilient is regarded as a cycle. Therefore, each adaptation phase is followed by an anticipation phase. However, if a company is well prepared, it might require fewer or no activities during the crisis itself.

The distribution of patterns according to the business model elements is illustrated in Table 3. By far the most frequent patterns are those assigned to key resources (52), followed by key activities (28). The explanation of this concentration relates to the high prevalence of patterns in the coping phase. When companies were forced to cope with the initial effects of the pandemic, existing resources and processes were the obvious starting point. A significant, yet only approximately half as large, number was assigned to key partners (23), which might be explained through supply chain difficulties arising. Sixteen patterns showed a relationship to the business model as a whole (row: "meta") signaling the need for broader measures to deal with the pandemic. In general, it shows that, across all patterns, the internal view of the business model (cost structure, key activities, key 
resource) is more in the foreground than is the external view (revenue stream, customer segments, channels, customer relationships, key partners).

Table 2. Objectives in the respective phases of resilience. Dark shades highlight the highest number of patterns in the respective objective cluster.

\begin{tabular}{|c|c|c|c|}
\hline \multirow[b]{2}{*}{ Objective } & \multicolumn{3}{|c|}{ Resilience Phases } \\
\hline & $\begin{array}{l}\text { Number of Patterns in } \\
\text { Anticipation Phase }\end{array}$ & $\begin{array}{l}\text { Number of Patterns in } \\
\text { Coping Phase }\end{array}$ & $\begin{array}{c}\text { Number of Patterns in } \\
\text { Adaption Phase }\end{array}$ \\
\hline $\begin{array}{l}\text { Increase transparency of the value } \\
\text { creation system }\end{array}$ & 3 & 3 & 2 \\
\hline Increase robustness & 6 & 2 & - \\
\hline $\begin{array}{c}\text { Create awareness on different scenarios } \\
\text { and risks }\end{array}$ & 10 & 4 & 4 \\
\hline Design a flexible system & 6 & 4 & 5 \\
\hline Empower people and create culture & 2 & 4 & 4 \\
\hline Enable agile actions & 4 & 6 & 1 \\
\hline Ensure employees' safety (in a health crisis) & - & 7 & 1 \\
\hline Ensure liquidity & 2 & 12 & 6 \\
\hline Adapt and align leadership & 4 & 7 & 3 \\
\hline Anticipate change in customer demand & 2 & 9 & 3 \\
\hline Use digital processes and work tools & 7 & 4 & 9 \\
\hline Identify revenue opportunities & - & 3 & 4 \\
\hline Anticipate moment of rebound & - & - & 6 \\
\hline Total & 47 & 65 & 48 \\
\hline
\end{tabular}

Table 3. Distribution of identified patterns across business model elements.

\begin{tabular}{cc}
\hline Business Model Element & Number of Patterns \\
\hline Meta & 16 \\
Key Partners & 23 \\
Key Activities & 28 \\
Key Resources & 52 \\
Value Proposition & 9 \\
Customer Relationships & 5 \\
Channels & 9 \\
Customer Segments & 8 \\
Cost Structure & 17 \\
Revenue Streams & 12 \\
\hline
\end{tabular}

\subsection{Validation}

The validation of the identified business model patterns, and the related classification according to resilience phases, objectives and business model elements, was based on a joint workshop with three company representatives from the electrical industry, as well as two representatives of ZVEI.

In the beginning, a short questionnaire for assessing the current and future relevance of industrial resilience for Germany's electrical industry was used. All participants agreed that issues related to industrial resilience gained importance during the COVID-19 pandemic and will become an even more important topic in the future.

Afterward, a qualitative discussion of the overall research approach, as well as of individual objectives and patterns related to the electrical industry, was conducted. Most of the patterns were assessed as very important or important by the participants. Some patterns assigned to the objectives "ensure revenue opportunities" and "ensure liquidity" were neither assessed as important nor as unimportant, as the representatives felt more confident about discussing patterns related to manufacturing and supply chain management due to their specific backgrounds. During the discussion, it was stated that the catalog of patterns is an important means for improving industrial resilience in the value creation 
of companies. However, it was pointed out that many patterns are rather generic and are applicable to any industry. Thus, it was noted that specific challenges of the electrical industry were not being sufficiently addressed. A core statement of the participants was that dual/second sourcing strategies often cannot be effectively realized, since only a few suppliers are globally capable of manufacturing complex electrical or electronic parts and products. This fact is currently also highlighted in the media, as a shortage of microelectronics and chips is hindering the manufacturing process of many companies. The shortage shows that manufacturing capacities of sufficient quality cannot be scaled up quickly, due to the high complexity of the required processes and produced products. Thus, the implementation of redundancies by emphasizing dual-sourcing strategies in value creation networks seems not to be a favorable approach for the electrical industry.

Since the identified objectives and patterns are non-industry-specific for the time being, it is necessary to interpret them against the background of the challenges faced by the electrical industry as described in Section 1 . The electrical industry as a whole shows a very high degree of connectivity with other sectors, and therefore covers a very diverse spectrum of products and services. This ranges from end-customer business for building automation and digital services in the healthcare sector, to highly specialized plant technology in industrial production. With this in mind, a collection of generic patterns (see Supplementary Table S1) is generally necessary to cover the wide range of potential challenges faced by individual companies. Nevertheless, several characteristics of the electrical industry must be considered to align the pattern catalog accordingly (see Table 4).

Table 4. Characteristics of the electrical industry in Germany and the resulting focus for the resilience patterns.

\begin{tabular}{|c|c|c|c|}
\hline $\begin{array}{l}\text { Characteristic of Electrical } \\
\text { Industry and Relevance } \\
\text { for Resilience }\end{array}$ & $\begin{array}{l}\text { Related Resilience } \\
\text { Objectives }\end{array}$ & $\begin{array}{l}\text { Related Business Model } \\
\text { Elements }\end{array}$ & $\begin{array}{l}\text { Resulting Focus for } \\
\text { Resilience Patterns } \\
\text { (Reference for Pattern ID in } \\
\text { Supplementary Table S1) }\end{array}$ \\
\hline $\begin{array}{l}\text { Mainly B2B-oriented: } \\
\text { long-term and more rational } \\
\text { business relationships but } \\
\text { limited overview of quickly } \\
\text { changing end-user markets }\end{array}$ & $\begin{array}{l}\text { - Anticipate change in } \\
\text { customer demand } \\
\text { - Anticipate moment } \\
\text { of rebound }\end{array}$ & $\begin{array}{ll}\text { - } & \text { Customer relationship } \\
\text { - } & \text { Customer segment } \\
\text { - } & \text { Channels }\end{array}$ & $\begin{array}{l}\text { Consider long-term } \\
\text { effects of prioritization } \\
\text { and pricing on } \\
\text { relationship with key } \\
\text { customers }(2.5 ; 2.10) \\
\text { Monitor behavior of } \\
\text { end-customers of } \\
\text { customers to anticipate } \\
\text { demand changes early } \\
\text { and dampen bullwhip } \\
\text { effect }(2.4 ; 3.3 ; 3.5)\end{array}$ \\
\hline $\begin{array}{l}\text { High share of turnover with } \\
\text { capital goods: higher } \\
\text { susceptibility to delayed } \\
\text { investments by customers }\end{array}$ & $\begin{array}{ll}\text { - } & \text { Anticipate change in } \\
\text { customer demand } \\
\text { - } & \text { Design flexible systems }\end{array}$ & $\begin{array}{ll}\text { - } & \text { Value proposition } \\
\text { - } & \text { Revenue streams }\end{array}$ & $\begin{array}{ll} & \text { Expand products with } \\
\text { supporting services to } \\
\text { generate continuous } \\
\text { revenue }(2.1 ; 2.9 ; 5.1) \\
\text { Utilize product-service } \\
\text { systems to provide } \\
\text { functionality instead of } \\
\text { ownership, to } \\
\text { accommodate flexible } \\
\text { demand and reduce } \\
\text { dependency regarding } \\
\text { financial investment } \\
\text { barriers }(2.2 ; 2.3 ; 2.4 ; 5.1)\end{array}$ \\
\hline
\end{tabular}


Table 4. Cont.

\begin{tabular}{|c|c|c|c|}
\hline $\begin{array}{l}\text { Characteristic of Electrical } \\
\text { Industry and Relevance } \\
\text { for Resilience }\end{array}$ & $\begin{array}{l}\text { Related Resilience } \\
\text { Objectives }\end{array}$ & $\begin{array}{l}\text { Related Business Model } \\
\text { Elements }\end{array}$ & $\begin{array}{l}\text { Resulting Focus for } \\
\text { Resilience Patterns } \\
\text { (Reference for Pattern ID in } \\
\text { Supplementary Table S1) }\end{array}$ \\
\hline $\begin{array}{l}\text { High portion of digital } \\
\text { products and services: ability } \\
\text { to support customers' } \\
\text { increased transparency and } \\
\text { flexibility needs to } \\
\text { address crises }\end{array}$ & $\begin{array}{ll}\text { - } & \text { Identify revenue } \\
\text { opportunities } \\
\text { - } \quad \text { Use digital processes and } \\
\text { work tools } \\
\text { - } \quad \text { Increase transparency of } \\
\text { value creation system }\end{array}$ & $\begin{array}{ll}- & \text { Key activities } \\
- & \text { Value proposition } \\
- & \text { Channels }\end{array}$ & 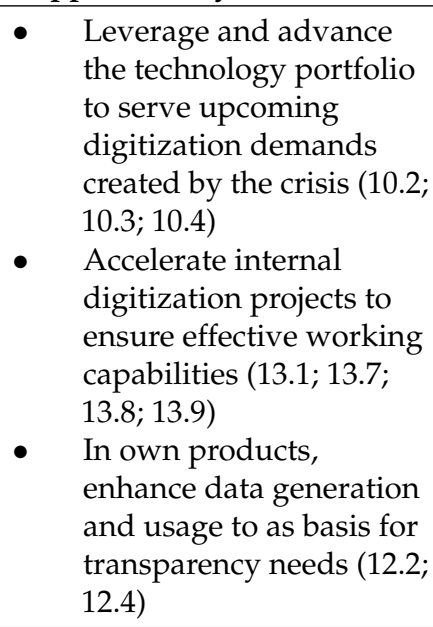 \\
\hline $\begin{array}{l}\text { High degree of innovation: } \\
\text { ability to realize new } \\
\text { technologies and applications } \\
\text { for changing needs }\end{array}$ & $\begin{array}{l}\text { Identify revenue } \\
\text { opportunities }\end{array}$ & $\begin{array}{ll}\text { - } & \text { Value proposition } \\
\text { - } & \text { Key activities }\end{array}$ & 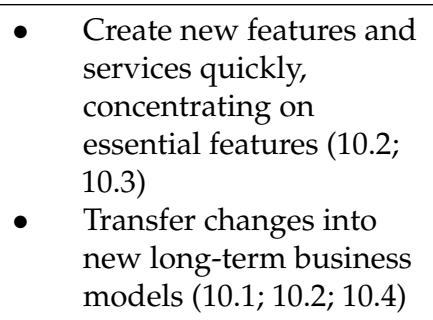 \\
\hline $\begin{array}{l}\text { High number of SME: faster } \\
\text { reaction capability but limited } \\
\text { financial and personnel } \\
\text { redundancies }\end{array}$ & $\begin{array}{ll}\text { - } & \text { Adapt and align } \\
\text { leadership } \\
\text { - } \quad \text { Empower people and } \\
\text { create culture } \\
\text { - } \quad \text { Ensure liquidity }\end{array}$ & - $\quad$ Key resources & 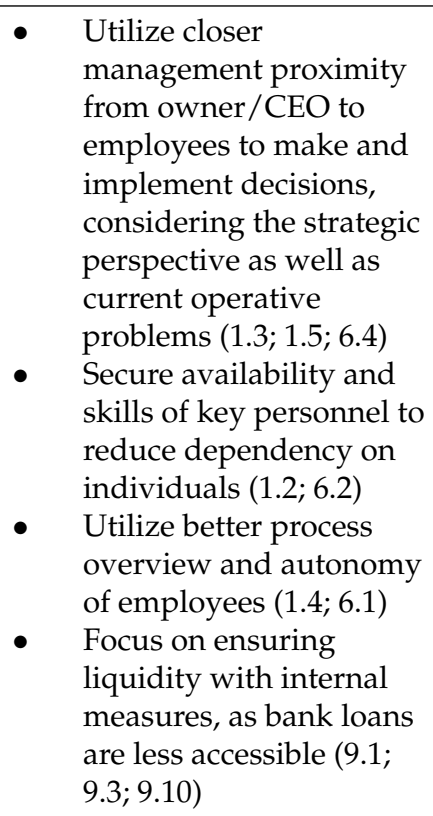 \\
\hline $\begin{array}{l}\text { Highly globally connected } \\
\text { supply chains with limited } \\
\text { supply alternatives: higher } \\
\text { susceptibility to impairments, } \\
\text { even locally. }\end{array}$ & $\begin{array}{ll}\text { - } & \text { Create awareness on } \\
\text { different scenarios and } \\
\text { risks } \\
\text { - } \quad \text { Design flexible systems } \\
\text { - } \quad \text { Increase robustness }\end{array}$ & $\begin{array}{ll}- & \text { Key partners } \\
- & \text { Key resources }\end{array}$ & $\begin{array}{l}\text { - } \quad \text { Monitor events and risks } \\
\text { on global (political) } \\
\text { landscape }(4.6 ; 4.7) \\
\text { - When redundancies and } \\
\text { alternatives cannot be } \\
\text { achieved by } \\
\text { dual-sourcing, adapt } \\
\text { inventory allocation and } \\
\text { prioritize customers (5.1; } \\
5.8 ; 5.10 ; 11.3)\end{array}$ \\
\hline
\end{tabular}


Most business models in the electrical industry are B2B-oriented, which simplifies communication, as customer contacts are mostly well defined and requirements are more explicit compared to the B2C market. However, when prioritizing individual customers in the event of shortages, greater attention must be paid to the long-term effects on the supplier-customer partnership. As the electrical industry is a driver for digitization and innovations, with digital products and services being elements of many business models, existing capabilities and activities can be leveraged to serve external demands quicker and translate new features into long-term post-crisis business models. At the same time, this provides opportunities to advance internal digitization roadmaps. Small and mediumsized companies (SMEs) make up the majority of the electrical industry. As SMEs have a limited access to external loans from the financial market for investments, in any case, patterns to ensure liquidity without relying on external sources need to be focused. On the other hand, the closer relationship between management and employees can be utilized to establish clear communication and decision making in a quicker and more credible manner. The high level of connectivity in global supply chains represents a major risk for electronics companies, as multiple regions have to be continuously monitored both from a demand and a supply perspective. At the same time, the global networks often cannot be used to create supply alternatives via dual-sourcing, as the necessary resources and components are often only available through very few suppliers. To compensate for this, companies need to resort more often to adapted inventory strategies and the prioritization of customers.

\section{Discussion and Future Recommendations}

The catalog is based on found statements in consulting publications, and therefore provides a picture of how to achieve resilience from a practical point of view, giving managerial recommendations. At the same time, it provides the basis for comparison with scientific literature. Practitioners can use the catalog in different ways. First, it gives a holistic overview of objectives and assigned patterns for reaching a state of higher resilience. Second, by combining resilience phases and patterns, it helps to shift the focus to what time each objective should be pursued. Third, by combining business model elements and patterns, the catalog on the one side helps to identify patterns that are suited to making single business model elements more resilient, and on the other side, the categorization simplifies the allocation of patterns within the organization. At the same time, this still is a general catalog; the suitability of each pattern for the specific question still needs to be checked every time. A company-specific solution also needs to be worked out by the practitioners. The interrelationship of the patterns was not investigated. It was assumed that each pattern in itself increases resilience.

There are, however, limitations to this study. First, only a few well-known consultancies were considered. Second, the approach concluded the search when a convergence criterion was reached. Continuing might deliver more insights; however, the number is expected to be very small. Third, in the course of this study, validation took place in a qualitative way in a single workshop, with experts from different companies from the German electrical industry. While it is unlikely, as the experts came from multinational organizations, it is possible that in other countries there will be a different result. Thus, applying the catalog to companies to gain insights on its applicability and usability constitutes a logical next step. Lastly, some patterns are certainly a reaction to the type of crisis. As COVID-19 was a health crisis, some patterns and objectives might be less relevant during other types of crisis, especially the cluster of ensuring employees' health and safety, which might be less relevant during non-health-related crises. The cluster regarding a change in customer demand might also be less oriented toward a digital channel during other crises.

Comparing the objectives against existing literature can give more insight into whether the proposed patterns extracted from consultancies improve resilience. As the objectives fit 
with resilience in the literature, and the patterns fit with the objectives, this can be seen as confirmation of the patterns.

The ability to come to a good decision quickly, among other factors, is influenced by leadership, decision-making structures and knowledge management, and the flexibility of an organization [9]. This confirms the general relevance of the objectives "adapt and align leadership" and "empower people and create culture". Defining a long-term vision (1.9) is seen as a positive factor for resilience [4]. According to the literature, including other opinions into the decision-making process, as well as decentralizing control [4], supports resilience. This confirms patterns 1.4 and 1.7. However, it contradicts pattern 1.3. A possible explanation is that, according to the analyzed literature, at different times, different leadership styles should be utilized. The focus on finding solutions quickly, rather than finding the perfect solution (1.6), is found in the literature as the term "bricolage" [78], which is seen as an important aspect of resilience [11]. Creating a culture where disruptions are seen as an opportunity, and which is supporting creativity [4,11], is a driver of resilience, yet this is not explicitly mentioned in the patterns. Having enough available personnel (6.2) and ensuring that they are motivated and aligned (6.4), e.g., by ensuring their wellbeing (6.5), can also be found in the literature [4].

The clusters "anticipate change in customer demand" and "anticipate moment of rebound" are not found in the literature with this particular focus. However, the implications of this focus on manufacturing and on fulfilling customer demands $(2.8,2.9,3.2,3.4,3.5)$ are important topics when addressing supply chain resilience [12].

The objective "create awareness on different scenarios and risks" can be found in many sources. Existing literature addresses the awareness of the environment in which the organization is operating, e.g., by building scenarios [9], and at the same time addresses managing potential negative impacts on the organization [9]. Organizations need to be able to observe the environment, identify possible threats, and prepare accordingly [3]. In this context, it is also important to recognize the problem [3]. Most of the patterns in this cluster are placed into the anticipation phase (see Table 2). This is in line with Duchek [3], where "observation and identification" [3] is placed in the anticipation phase. This capability in turn is closely related to the objective "increase transparency of the value creation system", as it is also related to the information within the system. Patterns can therefore be seen as relevant. The patterns related to the supply chain $(12.2,12.4,12.5)$ can also be found as visibility [12] in previous literature.

The objective "ensure liquidity" is focused on financial resource availability, as that was a particular focus within the analyzed publications. While that factor can also be found in the scientific literature $[3,4,6]$, there it is not only understood in terms of financial resources but also as the availability of other resource types.

The cluster "design a flexible system" can be found in the literature regarding supply chains [12]. Patterns within the objective "enable agile actions" are focused more on the ability of individuals to perform agile actions $[4,9,11]$, which has been covered above.

Redundancies to build robustness are mentioned especially in the literature $[3,4,6,12]$, and are therefore seen as relevant. Furthermore, the literature mentions the importance of networks and collaborations $[4,6]$, which is also represented by the pattern "preserve supplier networks on which you depend" in the objective of robustness.

The cluster "ensure health" is not mentioned explicitly in the literature. Nevertheless, the well-being of staff is mentioned in the literature [4,12]. The frequent mention in the analyzed sources of this objective is certainly a consequence of the COVID-19 pandemic being a health crisis. Therefore, it might be less relevant in other types of crisis; however, as it is also generalized in the literature it seems to be relevant to a certain point.

The patterns of "identify revenue opportunities" are not prevalent in the scientific literature. In contrast, liquidity and revenue generation are frequently mentioned in the grey literature of consultancies. This can be seen as too narrow a focus on short-term and reactive measures in the field of resilience management. On the other hand, it can 
also indicate a research gap regarding the criticality of available cash as a basis to survive a crisis.

The objective of "digital processes and work tools" is not directly represented in the scientific literature. The aspect of cybersecurity $(13.4,13.5)$ is, however, mentioned [12]. The analyzed literature stems mainly from the context of the COVID-19 pandemic, during which capabilities for remote working by utilizing digital tools were highly relevant. It can be assumed that digitization is not an unlimited measure for improving resilience and may also have negative effects in specific crisis situations.

An aspect that is highlighted by the literature is learning from the previous crisis and changing accordingly afterward [3]. This aspect was not present in the analyzed consulting literature; pattern 4.4 only partly includes it.

Further insights can be gained by comparing the results of this study with existing pattern collections from the business model domain. When matching the patterns with collections focusing on sustainability, the main differences persist with regard to the content of patterns and the structure or classification of patterns. In collections such as those by Lüdeke-Freund et al. [13] and by Lüdeke-Freund et al. [72], and Bocken et al. [73], contentwise focus is predominantly put on the environmental as well as the social dimension of business models. This aims to improve regular business performance with regard to these dimensions, while economic performance is also considered. When being applied to specific industries, as for example in the case of the banking industry, the patterns are adapted to that industry's characteristics [58]. Regarding the results of this study, this would entail adapting the pattern catalog to the electronic industry, which has not been realized at present. Crises in terms of single events that are needed to be dealt with are not explicitly focused on or taken into consideration in the mentioned collections.

The predominant focus on sustainability dimensions is also reflected in the structuring or classification of patterns in these collections. Patterns are clustered in topics related to the environmental and social dimension, e.g., creating value from waste, substituting with renewables and natural processes, and encouraging sufficiency [58], or are assigned to the three dimensions of sustainability or subdimensions of the sustainability triangle [13]. On the other hand, a similarity with regard to the current study persists in the fact that business model elements and underlying elements are partly applied to structuring or classifying patterns [72].

The comparison of the pattern catalog of this study to generic pattern collections draws a different picture. In contrast to the aforementioned pattern collections with a focus on sustainability, the economic performance seems to be in the foreground. Patterns that are related to social or environmental aspects are partly considered, but seemingly play a subordinate role here. Crises, on the other hand, are also not explicitly considered [56,57]. In relation to this study, it shows that although patterns of similar content are included in the generic pattern collections, especially those related to increasing revenue and decreasing costs, they are also related to sourcing and other aspects [43]. A further similarity with this study is the structuring or classification of patterns, which also takes into account business model elements and an overarching business model perspective [43]. Regarding the structuring of patterns, the contribution by Remane et al. [56] provides some insights on how structuring can be conducted in the case of specific industries. Here, the patterns are assigned to specific characteristics of the car-sharing business, which is in general a promising option for structuring existing collections according to specific industries.

Against the backdrop of the preceding explanations, it can be concluded that resilience has until now not been taken thoroughly into consideration in the context of business model patterns, although overlaps between the content of this study's catalog and existing collections exist. Thus, bringing the different collections together and structuring them according to the respective focus of business model development, e.g., improving resilience, seems promising. In this context, the structuring of patterns plays a very important role, as it determines the access to and the usability of collections. 
Besides the differences and commonalities between the different collections, their application requires a structured approach for target-oriented business model development. Therefore, the focus should be put on synergies between existing collections and further pattern-independent approaches. In the context of resilience, bringing this study's collection and, for example, the approaches by Carayannis et al. [14] and Biloslavo et al. [76] together, is a promising next step towards a systematic business model development for resilience.

\section{Conclusions and Outlook}

This study made a first attempt to fill the research gap related to the lack of pattern collections, with a focus on resilience. Based on publications by large consultancies, 110 unique patterns were identified and compiled in a catalog. For structuring the catalog and thereby enabling target-oriented access to the patterns, these were assigned to 13 objectives related to resilience, developed through clustering, and assigned to the three phases of resilience as well as to business model elements. The structured, yet generic, catalog was validated based on interviews with representatives of the German electrical industry. Additionally, the pattern catalog was analyzed and interpreted with regard to the characteristics of the German electrical industry. This resulted in the selection of patterns that are of high relevance for the industry, with industry-specific interpretations. These steps showed the catalog's general relevance, as well as its usefulness in the context of the electrical industry.

With regard to practice, the catalog thus provides companies with an overview and specific starting points for becoming more resilient, which can be selected according to company-specific needs. The assignment to the resilience phases and business model elements supports this selection. By improving the resilience capabilities of the valuecreation system through the identified patterns, companies can continue to contribute social and economic value, especially to local communities, while maintaining economic, ecological, and social resources. In this context, practitioners could be further assisted by catalogs that combine different targets like sustainability and resilience.

Furthermore, the structured catalog was analyzed with regard to relevant scientific literature, and differences as well as commonalities were identified, providing a variety of starting points for further research and development. In this regard, it showed that not all of the 13 objectives are represented in scientific literature, but that a general consistency exists. The analyzed publications showed a stronger focus on health concerns, revenue opportunities and digital processes, while the aspect of learning was less prevalent. The timing of the analysis, as well as the nature of the current crisis, might be causal for these circumstances, and future research should analyze the underlying reasons in more detail. In addition, subsequent research should repeat the approach chosen in this study after the pandemic, and see whether the identified patterns change.

Another starting point for further research persists in the analysis of existing pattern collections from the literature with a focus on patterns that are potentially relevant for resilience, to extend the structured catalog of this study. In addition, applying the catalog to specific industries and extending it by industry-specific patterns through case studies and literature analysis represents a promising opportunity to increase its relevance and usefulness for specific organizations. Further research could also consist in reviewing scientific and further literature independently of the current pandemic. In doing so, the catalog could be supplemented by scientific findings, as well as by experiences from other crises, such as the financial crisis and the ongoing disruptions between China and the USA. In addition to the pattern-based approach outlined in this article, further patternindependent approaches exist that also support companies in becoming more resilient, and that can be combined with this study's results to unlock synergy potential. Apart from the focus on resilience, merging existing pattern collections independent of their focus, e.g., sustainability, creating industry-specific or general collections, and developing 
classifications or taxonomies that enable demand-oriented or occasion-related access on this basis, represent great research and development potential.

Following up on the approach of the literature review as chosen in this contribution, the next logical step consists in the practical application of the catalog, e.g., in a case study approach to validate its effectiveness either within the electrical industry or outside. In the long run, this could result in the development and deployment of a maturity model that helps companies to follow a predefined path to resilience, based on their current status quo.

Supplementary Materials: The following are available online at https:/ / www.mdpi.com/article/10 $.3390 /$ su13116090/s1, Table S1: Catalog of patterns.

Author Contributions: Conceptualization, K.N., T.v.E. and F.S.; methodology, K.N., T.v.E., E.S. and F.S.; validation, K.N., T.v.E., E.S. and F.S.; formal analysis, K.N., T.v.E., E.S. and F.S.; investigation, K.N., T.v.E., E.S. and F.S.; data curation, K.N., T.v.E., E.S. and F.S.; writing-original draft preparation, K.N., T.v.E., E.S. and F.S.; writing-review and editing, K.N., T.v.E., E.S., F.S. and H.K.; funding acquisition, K.N.; visualization, T.v.E.; project administration, F.S. All authors have read and agreed to the published version of the manuscript.

Funding: This research received no external funding.

Institutional Review Board Statement: Not applicable.

Informed Consent Statement: Not applicable.

Data Availability Statement: The data presented in this study are available in Supplementary Material Table S1.

Acknowledgments: The authors thank the German Electrical and Electronic Manufacturers' Association (ZVEI) and the participants of the joint workshop as well as the reviewers for their reviews and valuable comments.

Conflicts of Interest: The authors declare no conflict of interest.

\section{References}

1. Bhamra, R.; Dani, S.; Burnard, K. Resilience: The concept, a literature review and future directions. Int. J. Prod. Res. 2011, 49, 5375-5393. [CrossRef]

2. Burnard, K.; Bhamra, R. Organisational resilience: Development of a conceptual framework for organisational responses. Int. J. Prod. Res. 2011, 49, 5581-5599. [CrossRef]

3. Duchek, S. Organizational resilience: A capability-based conceptualization. Bus. Res. 2020, 13, 215-246. [CrossRef]

4. Barasa, E.; Mbau, R.; Gilson, L. What Is Resilience and How Can It Be Nurtured? A Systematic Review of Empirical Literature on Organizational Resilience. Int. J. Health Policy Manag. 2018, 7, 491-503. [CrossRef]

5. Kamalahmadi, M.; Parast, M.M. A review of the literature on the principles of enterprise and supply chain resilience: Major findings and directions for future research. Int. J. Prod. Econ. 2016, 171, 116-133. [CrossRef]

6. Ruiz-Martin, C.; Lopez-Paredes, A.; Wainer, G. What we know and do not know about organizational resilience. Int. J. Prod. Manag. Eng. 2018, 6, 11-28. [CrossRef]

7. Vogus, T.J.; Sutcliffe, K.M. Organizational resilience: Towards a theory and research agenda. In Proceedings of the 2007 IEEE International Conference on Systems, Man and Cybernetics, Montreal, QC, Canada, 7-10 October 2007; IEEE Service Center: Piscataway, NJ, USA, 2007; pp. 3418-3422, ISBN 978-1-4244-0990-7.

8. Gittell, J.H.; Cameron, K.; Lim, S.; Rivas, V. Relationships, Layoffs, and Organizational Resilience. J. Appl. Behav. Sci. 2006, 42, 300-329. [CrossRef]

9. McManus, S.; Seville, E.; Vargo, J.; Brunsdon, D. Facilitated Process for Improving Organizational Resilience. Nat. Hazards Rev. 2008, 9, 81-90. [CrossRef]

10. Christopher, M.; Peck, H. Building the Resilient Supply Chain. Int. J. Logist. Manag. 2004, 15, 1-14. [CrossRef]

11. Mallak, L. Putting Organizational Resilience to Work. Ind. Manag. Chic. Atlanta 1998, 40, 8-13.

12. Fiksel, J.; Polyviou, M.; Croxton, K.L.; Pettit, T.J. From Risk to Resilience Learning to Deal with Disruption. MIT Sloan Manag. Rev. 2015, 56, 79-86.

13. Lüdeke-Freund, F.; Carroux, S.; Joyce, A.; Massa, L.; Breuer, H. The sustainable business model pattern taxonomy-45 patterns to support sustainability-oriented business model innovation. Sustain. Prod. Consum. 2018, 15, 145-162. [CrossRef]

14. Carayannis, E.G.; Grigoroudis, E.; Sindakis, S.; Walter, C. Business Model Innovation as Antecedent of Sustainable Enterprise Excellence and Resilience. J. Knowl. Econ. 2014, 5, 440-463. [CrossRef]

15. Dori, D. Conceptual Modeling: Purpose and Context. In Model-Based Systems Engineering with OPM and SysML, 1st ed.; Dori, D., Ed.; Springer: New York, NY, USA, 2016; pp. 75-96, ISBN 978-1-4939-3295-5. 
16. Stock, T.; Seliger, G. Methodology for the Development of Hardware Startups. Adv. Mater. Res. 2016, 1140, 505-512. [CrossRef]

17. United Nations. United Nations Sustainable Development: 17 Goals to Transform Our World. Available online: https://www.un. org/sustainabledevelopment/ (accessed on 21 April 2021).

18. Denton, F.; Wilbanks, T.; Burton, I.; Chandani, A.; Gao, Q.; Lemos, M.C.; Masui, T.; O’Brien, K.; Warner, K.; Dickinson, T.; et al. Climate-resilient pathways: Adaptation, Mitigation, and Sustainable Development. In Climate Change 2014: Impacts, Adaptation, and Vulnerability. Part A: Global and Sectoral Aspects. Contribution of Working Group II to the Fifth Assessment Report of the Intergovernmental Panel on Climate Change; Field, C.B.V.R., Barros, D.J., Dokken, K.J., Mach, M.D., Mastrandrea, T.E., Bilir, M., Chatterjee, K.L., Ebi, Y.O., Estrada, R.C., Genova, B., et al., Eds.; Cambridge University Press: Cambridge, UK; New York, NY, USA, 2014; pp. 1101-1131. Available online: https://www.ipcc.ch/site/assets/uploads/2018/02/WGIIAR5-Chap20_FINAL.pdf (accessed on 21 April 2021).

19. United Nations. Goal 13 I Department of Economic and Social Affairs. Available online: https://sdgs.un.org/goals/goal13 (accessed on 21 April 2021).

20. United Nations. Goal 11 I Department of Economic and Social Affairs. Available online: https://sdgs.un.org/goals/goal11 (accessed on 21 April 2021).

21. United Nations. Goal 9/Department of Economic and Social Affairs. Available online: https://sdgs.un.org/goals/goal9 (accessed on 21 April 2021).

22. Ortiz-de-Mandojana, N.; Bansal, P. The long-term benefits of organizational resilience through sustainable business practices. Strat. Mgmt. J. 2016, 37, 1615-1631. [CrossRef]

23. ZVEI-German Electrical and Electronic Manufacturers' Association. German Electric Industry-Facts \& Figures. Available online: https:/ / www.zvei.org/fileadmin/user_upload/Presse_und_Medien/Publikationen/Regelmaessige_Publikationen/ Daten_Zahlen_und_Fakten/Die_deutsche_Elektroindustrie_Daten_Zahlen_Fakten/Fact-Sheet-March-2021_V2.pdf (accessed on 19 April 2021).

24. ZVEI. Divisions. Available online: https://www.zvei.org/en/association/divisions (accessed on 19 April 2021).

25. ZVEI-German Electrical and Electronic Manufacturers' Association. ZVEI-Foreign-Trade-Report-March-2021. Available online: https: / / www.zvei.org/fileadmin/user_upload/Presse_und_Medien/Publikationen/2021/Maerz/ZVEI-Aussenhandelsreport_ Maerz_2021/ZVEI-Foreign-Trade-Report-March-2021.pdf (accessed on 19 April 2021).

26. ZVEI. Ergebnisse der ZVEI-Umfrage. Available online: https://www.zvei.org/themen/maerkte-recht/konjunktur-analysen/ ergebnisse-der-zvei-umfrage (accessed on 16 January 2021).

27. Jürgen Polzin. Ergebnisse der Dritten Ad-hoc-Umfrage zur Corona-Krise. Available online: https://www.zvei.org/ presse-medien/newsletter/auf-den-punkt-3/2020-zvei-newsletter/ergebnisse-der-dritten-ad-hoc-umfrage-zur-corona-krise (accessed on 16 January 2021).

28. ZVEI-Zentralverband Elektrotechnik-und Elektronikindustrie e. V. ZVEI-Konjunkturbarometer-Dezember-2020. Available online: https://www.zvei.org/fileadmin/user_upload/Presse_und_Medien/Publikationen/2020/Dezember/ZVEIKonjunkturbarometer_Dezember_2020/ZVEI-Konjunkturbarometer-Dezember-2020.pdf (accessed on 16 January 2021).

29. Stock, T.; Obenaus, M.; Kunz, S.; Kohl, H. Industry 4.0 as enabler for a sustainable development: A qualitative assessment of its ecological and social potential. Process. Saf. Environ. Prot. 2018, 118, 254-267. [CrossRef]

30. Stock, T.; Seliger, G. Opportunities of Sustainable Manufacturing in Industry 4.0. Procedia CIRP 2016, 40, 536-541. [CrossRef]

31. Dalziell, E.P.; McManus, S.T. Resilience, Vulnerability, and Adaptive Capacity: Implications for System Performance. In Proceedings of the 1st International Forum for Engineering Decision Making (IFED), Stoos, Switzerland, 5-8 December 2004.

32. ZVEI-German Electrical and Electronic Manufacturers' Association. Technological-Sovereignty-Industrial-Resilience-andEuropean-Competences-Discussion-Paper 2020. Available online: https://www.zvei.org/fileadmin/user_upload/Presse_ und_Medien/Publikationen/2020/Oktober/Technologische_Souveraenitaet_Resilienz_der_Industrie_und_europaeische_ Kompetenzen/Technological-Sovereignty-Industrial-Resilience-and-European-Competences-Discussion-Paper.pdf (accessed on 14 March 2021).

33. Linnenluecke, M.K. Resilience in Business and Management Research: A Review of Influential Publications and a Research Agenda. International Journal of Management Reviews. Int. J. Manag. Rev. 2017, 19, 4-30. [CrossRef]

34. Resilien-Tech. Resilience-by-Design Strategie für die Technologischen Zukunftsthemen; Thoma, K., Ed.; Utz: Munchen, Germany, 2014; ISBN 978-3-8316-4375-2.

35. Morris, M.; Schindehutte, M.; Allen, J. The entrepreneur's business model: Toward a unified perspective. J. Bus. Res. 2005, 58, 726-735. [CrossRef]

36. Osterwalder, A.; Pigneur, Y. Business Model Generation: A Handbook for Visionaries, Game Changers, And Challengers; Wiley: Hoboken, NJ, USA, 2010; ISBN 0470876417.

37. Wirtz, B.W.; Pistoia, A.; Ullrich, S.; Göttel, V. Business Models: Origin, Development and Future Research Perspectives. Long Range Plan. 2016, 49, 36-54. [CrossRef]

38. Afuah, A.; Tucci, C.L. Internet Business Models and Strategies: Text and Cases, 2nd ed.; McGraw Hill: Boston, MA, USA, 2003; ISBN 0-07-115123-0.

39. Pateli, A.G.; Giaglis, G.M. A research framework for analysing eBusiness models. Eur. J. Inf. Syst. 2004, 13, 302-314. [CrossRef]

40. Teece, D.J. Business Models, Business Strategy and Innovation. Long Range Plan. 2010, 43, 172-194. [CrossRef] 
41. Schallmo, D. Geschäftsmodell-Innovation: Grundlagen, Bestehende Ansätze, Methodisches Vorgehen und B2B-Geschäftsmodelle; Springer Gabler: Wiesbaden, Germany, 2013; ISBN 9783658002442.

42. Gassmann, O.; Frankenberger, K.; Csik, M. The Business Model Navigator: 55 Models that Will Revolutionise Your Business; Pearson: Harlow, UK, 2014; ISBN 978-1-292-06581-6.

43. Remane, G.; Hanelt, A.; Tesch, J.F.; Kolbe, L.M. The business model pattern database-A tool for systamatic business model innovation. Int. J. Innov. Mgt. 2017, 21, 1750004. [CrossRef]

44. Abdelkafi, N.; Makhotion, S.; Posselt, T. Business Model Innovations for Electric Mobility—What can be learned from existing business model patterns? Int. J. Innov. Mgt. 2013, 17, 1-41. [CrossRef]

45. Gausemeier, J.; Amshoff, B. Diskursive Geschäftsmodellentwicklung-Erfolgreiche Positionierung in der Wettbewerbsarena durch integrative Entwicklung von Marktleistung und Geschäftsmodell. ZwfZ. Für Wirtsch. Fabr. 2014, 109, 428-434.

46. Gassmann, O.; Frankenberger, K.; Choudury, M. Geschäftsmodelle Entwickeln: 55+ Innovative Konzepte mit dem St. Galler Business Model; Navigator, 3.; Überarbeitete und Erweiterte Auflage; Hanser: München, Germany, 2021; ISBN 9783446465213.

47. Johnson, M.W. Seizing the White Space: Business Model Innovation for Growth and Renewal; Harvard Business Press: Boston, MA, USA, 2010; ISBN 9781422124819.

48. Weill, P.; Vitale, M.R. Place to Space: Migrating to eBusiness Models; Harvard Business School Press: Boston, MA, USA, 2001; ISBN 157851245X.

49. Linder, J.; Cantrell, S. Changing Business Models: Surveying the Landscape. Working Paper. Accenture Institute for Strategic Change: Cambridge, MA, USA, 2000.

50. Tuff, G.; Wunker, S. Beacons for Business Model Innovation. Available online: http://cdn2.hubspot.net/hub/88808/file-890913 188-pdf/docs/beacons_for_busniess_model_innovation_download.pdf (accessed on 19 October 2018).

51. Rappa, M. Managing the Digital Enterprise: Business Models on the Web. Available online: http://digitalenterprise.org/models/ models.pdf (accessed on 26 October 2018).

52. Taran, Y.; Nielsen, C.; Montemari, M.; Thomsen, P.; Paolone, F. Business model configurations: A five-V framework to map out potential innovation routes. Eur. J. Innov. Manag. 2016, 19, 492-527. [CrossRef]

53. Massa, L.; Tucci, C.L. Business Model Innovation. In The Oxford Handbook of Innovation Management; Dodgson, M., Gann, D.M., Phillips, N., Eds.; OUP: Oxford, UK, 2014; pp. 420-441. ISBN 9780199694945.

54. Amshoff, B.; Dülme, C.; Echterfeld, J.; Gausemeier, J. Business model patterns for disruptive technologies. Int. J. Innov. Manag. 2015, 19, 1540002. [CrossRef]

55. Amshoff, B. Systematik zur Musterbasierten Entwicklung Technologie-Induzierter Geschäftsmodelle: Approach for a Pattern-Based Design of Technology-Induced Business Models; Heinz Nixdorf Institut, Universität Paderborn: Paderborn, Germany, 2016; ISBN 3942647761.

56. Remane, G.; Nickerson, R.C.; Hanelt, A.; Tesch, J.F.; Kolbe, L.M. A Taxonomy of Carsharing Business Models. In Proceedings of the 37th International Conference on Information Systems, Dublin, Irland, 11-14 December 2016.

57. Weking, J.; Hein, A.; Böhm, M.; Krcmar, H. A hierarchical taxonomy of business model patterns. Electr. Mark 2018, 17, 359. [CrossRef]

58. Yip, A.W.; Bocken, N.M. Sustainable business model archetypes for the banking industry. J. Clean. Prod. 2018, 174, 150-169. [CrossRef]

59. Reinhold, S.; Beritelli, P.; Grünig, R. A business model typology for destination management organizations. Tour. Rev. 2019, 74, 1135-1152. [CrossRef]

60. Hedman, J.; Kalling, T. The business model concept: Theoretical underpinnings and empirical illustrations. Eur. J. Inf. Syst. 2003, 12, 49-59. [CrossRef]

61. Zott, C.; Amit, R.; Massa, L. Working Paper. In The Business Model: Theoretical Roots, Recent Developments, and Future Research; University of Navarra: Barcelona, Spain, 2010.

62. Wise, R.; Morrison, D. Beyond the exchange-The future of B2B. Harv. Bus. Rev. 2000, 78, 86-96. [PubMed]

63. Hunke, F.; Schüritz, R.; Kuehl, N. Towards a unified approach to identify business model patterns: A case of e-mobility services. Lect. Notes Bus. Inf. Process. 2017, 279, 182-196. [CrossRef]

64. Zeleti, F.A.; Ojo, A.; Curry, E. Emerging business models for the open data industry: Characterization and analysis. In Proceedings of the ACM International Conference Proceeding Sereries, Aguascalientes, Mexico, 18-21 June 2014. [CrossRef]

65. Fleisch, E.; Weinberger, M.; Wortmann, F. Business models and the internet of things. In Interoperability and Open-Source Solutions for the Internet of Things; Springer: Cham, Switzerland, 2015; pp. 6-10.

66. Kobler, D. Innovative Geschäftsmodelle: Entwicklung und Gestaltung innovativer Geschäftsmodelle für Schweizer Versicherungsunternehmen im Privatkundensegment Hamburger Schriften zur Marketingforschung; Rainer Hampp Verlag: München und Mering, Germany, 2005; ISBN 3879889686.

67. Alter, S.K. Social enterprise models and their mission and money relationships. In Social Entrepreneurship: New Models of Sustainable Social Change; Oxford University Press: Oxford, UK, 2006; pp. 205-232.

68. Dohrmann, S.; Raith, M.; Siebold, N. Monetizing Social Value Creation-A Business Model Approach. Entrep. Res. J. 2015, 5, 308. [CrossRef]

69. Rappa, M.A. The utility business model and the future of computing services. IBM Syst. J. 2004, 43, 32-42. [CrossRef]

70. Schallmo, D.R. Geschäftsmodelle erfolgreich entwickeln und implementieren: Mit Aufgaben, Kontrollfragen und Templates, 2nd ed.; Springer Gabler: Berlin, Germany, 2018; ISBN 9783662576045. 
71. Albino, V.; Fraccascia, L. The Industrial Symbiosis Approach: A Classification of Business Models. Procedia Environ. Sci. Eng. Manag. 2015, 2, 217-223.

72. Lüdeke-Freund, F.; Gold, S.; Bocken, N.M. A Review and Typology of Circular Economy Business Model Patterns. J. Ind. Ecol. 2019, 23, 36-61. [CrossRef]

73. Bocken, N.; Short, S.W.; Rana, P.; Evans, S. A literature and practice review to develop sustainable business model archetypes. J. Clean. Prod. 2014, 65, 42-56. [CrossRef]

74. Dressler, M.; Paunović, I. Towards a conceptual framework for sustainable business models in the food and beverage industry. Br. Food J. 2020, 122, 1421-1435. [CrossRef]

75. Reinhardt, R.; Christodoulou, I.; García, B.A.; Gassó-Domingo, S. Sustainable business model archetypes for the electric vehicle battery second use industry: Towards a conceptual framework. J. Clean. Prod. 2020, 254, 119994. [CrossRef]

76. Biloslavo, R.; Bagnoli, C.; Edgar, D. An eco-critical perspective on business models: The value triangle as an approach to closing the sustainability gap. J. Clean. Prod. 2018, 174, 746-762. [CrossRef]

77. consultancy.uk. The 10 Largest consulting Firms in the World. Available online: https://www.consultancy.uk/news/14018/the10-largest-consulting-firms-in-the-world (accessed on 22 March 2021).

78. Weick, K.E. The Collapse of Sensemaking in Organizations: The Mann Gulch Disaster. Adm. Sci. Q. 1993, 38, 628. [CrossRef] 